\title{
THE BOOK OF THE DEAD MAN (CONVERSATION)
}

\author{
Live as if you were already dead. \\ -Zen admonition
}

\section{岕}

\section{About the Dead Man's Conversations}

The dead man hath spoken with Matthew Arnold about ignorant armies.

He hath cautioned Keats on the isolate love of beauty.

If there were ever Grecian odes on the shore, they were smashed in the general onslaught.

Like sand castles adrift in the idea of architecture, like basreliefs planed to the texture of papyrus, like rubber in acid, the repositories of beauty did not outlast the idea of them.

The dead man is of a mind, and a mind to, and his exploration has been in the places where an idea may fit.

It has been a long thrill in the dark for the dead man and friends.

The dead man is on the side of art but also on the side of artlessness.

Absent the blank page, the word must forever be muddied.

The words can be true only to one another, like Arnold's lovers -the ideal.

Well, says the dead man, what have we here?

It seems the dead man has caught the words in a compromising position.

This verbal interruptus is aquiver from circling an invisible vase where the lovers have been trying to catch one another.

Must poetry forever be anticipation and delayed gratification? The dead man has been talking with T. S. Eliot about escaping one's personality, which he has.

\section{The Iowa Review}


And with Wallace Stevens about the mind in the act of finding what will suffice, which he has.

The dead man, too, can write the tautologies that cloak war and torture.

But he no longer cottons to the aesthetic tilt of a head, the legendary voice, the prophetic boom box or starlit ego.

Why should the dead man use up his life in the usual ways?

The dead man's poetry is not stone cold soup.

\section{More About the Dead Man's Conversations}

It was cold in the coffee house where the dead man met the editor.

The dead man had asked Henry James if there could be two congruent points of view.

He had challenged William James to a bout of automatic writing.

The dead man won the game of exquisite corpse when he folded the paper twice.

He wrote faster and faster, but he could not get down everything.

The engineers were of a mind to map a brain -an empty brain.

When the dead man and the editor met, it was in the early years of the Apocalypse.

That no one could conceive of everything had given the lie to prophecy.

It was a time when string theory was unraveling, when relativity had become absolute, when Gurdjieff s "all and everything" subsumed the cults, clans, castes, tribes, and schools.

The dead man's papers had been overwritten. It was up to the editor to select a sample. 
The dead has lived among remnants, shards, fragments, doubles, and replicas, among lucky error and deliberate effect.

Like a snake, the dead man molts, leaving a whole skin now passé.

How shall the editor edit the seamless if not with scissors?

The dead man has been talking to James Joyce about not being there when his words end up new.

The dead man has been talking to Galileo about the Law of Falling Bodies, which applies.

How shall the editor edit the perpetual or eternal if not with scissors?

The dead man's world is kaleidoscopic, it turns without stopping.

Say you knew him, but not what he was thinking. 